\title{
ANALISIS KINERJA PERUSAHAAN SEBELUM DAN SESUDAH MERGER DAN AKUISISI \\ (STUDI EMPIRIS PADA PERUSAHAAN NON-KEUANGAN YANG TERDAFTAR DI BURSA EFEK INDONESIA TAHUN 2009-2017)
}

\author{
Cecilia Chandra Halim \\ Program Studi Magister Manajemen Universitas Tarumanagara \\ halim.ceciliachandra@gmail.com \\ Indra Widjaja \\ Program Studi Magister Manajemen Universitas Tarumanagara \\ Masuk : 30-10-2019, revisi : 05-12-2019 diterima untuk diterbitkan : 05-12-2019
}

\begin{abstract}
It is undeniable that the world is moving towards to an era of mergers and acquisitions (M\&A). M\&A that emerged in Asia began with a change in policy after the economic crisis. In the period of 2012 - 2015, based on reports from McKinsey and Reuters showed an increase in the value of mergers and acquisitions in Indonesia amounted to $16.7 \%$, which at the same time M\&A in the Asia Pacific and the world experienced a decline. The purpose of this study is to analyze the Companies performance that conduct M\&A both in terms of financial and market value. The samples in this study consisted of 16 non-financial companies listed on the Indonesia Stock Exchange in the period 2009-2017. Financial performance will be measured using financial ratios and market performance will be measured using Tobin's $Q$ ratio. The results of this study indicate that it takes a long time to show that there is a synergy between companies conducting mergers and acquisitions.
\end{abstract}

Keywords : Merger and Acquisition, Financial Performance, Market Performance, Nonfinancial industry, Indonesia

\begin{abstract}
Abstrak : Tak dapat dipungkiri bahwa dunia sedang berjalan menuju era merger dan akusisi (M\&A). M\&A yang muncul di Asia diawali oleh adanya perubahan kebijakan setelah krisis ekonomi. Pada periode tahun 2012 - 2015, berdasarkan laporan dari McKinsey dan Reuters menunjukan adanya peningkatan nilai M\&A di Indonesia yaitu sebesar 16.7\%, dimana pada saat yang sama M\&A se-Asia Pasifik dan sedunia mengalami penurunan. Tujuan dari penelitian ini adalah menganalisis kinerja perusahaan yang melakukan merger dan akuisisi baik dari sisi keuangan dan nilai pasar. Sampel pada penelitian ini terdiri dari 16 perusahaan nonkeuangan yang terdaftar di BEI pada periode 2009-2017. Kinerja keuangan akan diukur menggunakan rasio keuangan dan kinerja pasar akan diukur menggunakan rasio Tobin's Q. Hasil dari penelitian ini menunjukkan bahwa dibutuhkan waktu yang panjang untuk menunjukkan bahwa terjadi sinergi antara perusahaan yang melakukan merger dan akuisisi.
\end{abstract}

Kata Kunci : Merger dan akuisisi, kinerja keuangan, kinerja pasar, industri non-keuangan, Indonesia

\section{PENDAHULUAN}

Tak dapat dipungkiri bahwa dunia sedang berjalan menuju era merger dan akusisi (M\&A). Merger dan akuisisi yang muncul di Asia diawali oleh adanya perubahan kebijakan setelah krisis ekonomi. Oleh karena itu sebagian besar orang berharap bahwa M\&A ini dapat membantu memperbaiki kondisi perusahaan, dan restrukturisasi keuangan dapat dengan cepat terealisasi. Selain itu, M\&A diharapkan dapat memfasilitasi pemulihan ekonomi dari krisis 
yang timbul. Banyak perusahaan global mulai berpaling dari sekedar membangun usaha baru ke merger ataupun akusisi. Pada periode tahun 2012 - 2015, berdasarkan laporan dari McKinsey dan Reuters menunjukan adanya peningkatan nilai merger dan akusisi di Indonesia yaitu sebesar $16.7 \%$, dimana pada saat yang sama merger dan akuisisi se-Asia Pasifik dan sedunia mengalami penurunan. Kenaikan ini menjadi indikator bahwa investor mulai menjadikan Indonesia sebagai tujuan investasi yang jika dapat berjalan dengan baik akan memberikan efek yang positif bagi perekonomian Indonesia di masa mendatang.

Setelah suatu pelaku usaha memutuskan untuk melakukan merger dan akuisisi sebagai strategi untuk berkembang maupun bertahan, maka diperlukan adanya penilaian kinerja dari pelaku bisnis tersebut. Penilaian kinerja dapat dilakukan dengan membandingkan kondisi keuangan dan kinerja pasar sebelum dan sesudah dilakukannya merger dan akuisisi. Jika kondisi keuangan dan kinerja pasar perusahaan membaik setelah melakukan merger dan akuisisi maka dapat disimpulkan bahwa keputusan yang diambil tersebut tepat. Namun sebaliknya, jika kondisi keuangan dan kinerja pasar perusahaan menurun setelah merger dan akuisisi dilakukan maka keputusan ini kurang tepat untuk dilakukan.

Berdasarkan referensi yang digunakan oleh peneliti mengenai merger dan akuisisi ini, rasio keuangan yang dapat digunakan untuk mengukur kinerja keuangan perusahaan antara lain current ratio, quick ratio, total asset turnover, return on asset, return on equity, earnings per shares, net profit margin, debt to equity ratio, dan times interest earned serta untuk menganalisa kinerja pasar akan digunakan rasio Tobin's $Q$.

Berdasarkan latar belakang penelitian di atas, judul yang dipilih adalah "ANALISIS KINERJA PERUSAHAAN SEBELUM DAN SESUDAH MERGER DAN AKUISISI (STUDI EMPIRIS PADA PERUSAHAAN NON-KEUANGAN YANG TERDAFTAR DI BURSA EFEK INDONESIA TAHUN 2009-2017)”.

\section{RUMUSAN MASALAH}

Berdasarkan latar belakang tersebut maka pokok permasalahan yang akan dibahas dalam penelitian ini adalah apakah merger dan akuisisi berpengaruh signifikan terhadap kinerja keuangan dan kinerja pasar perusahaan.

\section{LANDASAN TEORI}

Merger dapat didefinisikan sebagai penggabungan antara dua perusahaan atau lebih, dimana hanya ada satu perusahaan yang bertahan $(A+B=A / B)$ sedangkan akuisisi merupakan salah satu jenis dari merger dimana suatu perusahaan mengambil alih kepemilikan perusahaan lain. Merger dan akuisisi menjadi salah satu strategi yang dapat dipilih oleh perusahaan untuk mendorong pertumbuhan, melakukan sinergi dan diversifikasi. Alasan yang mendasari suatu perusahaan memilih melakukan merger dan akuisisi adalah pertama, meningkatkan nilai perusahaan yang diukur menggunakan perolehan laba. Peningkatan laba tersebut akan meningkatkan kesejahteraan dari pemegang saham perusahaan yang diambil-alih. Sebelum melakukan merger dan akuisisi, kinerja perusahaan yang diambil-alih belum mencapai kapasitas maksimalnya. Kedua, merger dan akuisisi merupakan kepentingan managemen perusahaan yang ingin memperoleh keuntungan dengan mengorbankan keuntungan pemegang saham. (Tarigan, Yenewa, dan Natalia, 2016:33). Sinergi merupakan sesuatu yang terbentuk dari merger dan akuisisi. Ada dua motif sinergi yang dapat terbentuk dari merger dan akuisisi yaitu motif sinergi operasional dan keuangan. Sinergi operasional terbentuk apabila perusahaan dapat mencapai kondisi economics of scale dan economics of scope sedangkan sinergi keuangan terbentuk apabila perusahaan dapat meningkatkan pendapatan dan mengurangi biaya operasinya. Namun dari semua sisi positif merger dan akuisisi terdapat sisi negatif yang tidak dapat dipungkiri yaitu dalam prakteknya, keputusan melakukan merger dan akuisisi ini juga didorong oleh keinginan pemilik usaha untuk menguasai pasar (Gaughan,2007:117). 
Kinerja keuangan dari suatu perusahaan dapat diukur dengan mengevaluasi tiga karakteristik yaitu likuiditas, profitabilitas dan solvabilitas (Weygandt, Kimmel dan Kieso,2011:660). Rasio likuiditas merupakan rasio yang digunakan untuk mengukur kemampuan perusahaan melunasi kewajiban jangka pendek dan memenuhi kebutuhan kas yang tidak terduga yang dapat diproksikan dengan current ratio, quick ratio, receivable turnover dan inventory turnover. Rasio profitabilitas merupakan rasio yang digunakan untuk mengukur pendapatan perusahaan untuk jangka waktu tertentu yang diproksikan dengan net profit margin, total assets turnover, return on assets, return on equity, earning per shares, price earnings ratio, dan payout ratio. Rasio solvabilitas merupakan rasio yang digunakan untuk mengukur kemampuan bertahan suatu perusahaan dalam jangka waktu yang panjang yang diproksikan dengan debt to total assets ratio, debt to equity ratio dan time interest earned. Analisis kinerja keuangan dapat digunakan oleh manajemen perusahaan untuk menentukan seberapa baik kinerja keuangan yang telah dicapai oleh perusahaan dan sebagai bahan evaluasi untuk dapat meningkatkan kinerja perusahaan.

Tujuan utama berdirinya suatu perusahaan adalah meningkatkan nilai perusahaan demi meningkatkan kesejateraan dari pemegang saham. Peningkatan nilai perusahaan dapat dilihat melalui besaran harga yang bersedia dibayarkan oleh calon pemegang saham apabila perusahaan tersebut dijual. Nilai perusahaan ini kemudian menjadi indikator yang digunakan oleh pemegang saham untuk mengukur tingkat keberhasilan dari operasional suatu perusahaan. Tobin's $Q$ ratio merupakan suatu model yang digunakan untuk menunjukkan kinerja pasar perusahaan atau menghitung nilai perusahaan. Rasio Tobin's $Q$ ini dianggap paling baik untuk memberikan informasi terkait dengan kegiatan merger dan akuisisi karena didalam rumusan rasio ini memasukkan semua unsur modal saham dan hutang perusahaan.

Penelitian terdahulu yang dilakukan oleh Payamta dan Setiawan (2004:279) dan Harjito dan Sulong (2006:10) menyatakan bahwa tidak terjadi perbaikan likuiditas perusahaan setelah merger dan akuisisi dan tingkat profitabilitas perusahaan mengalami penurunan sesudah merger dan akuisisi. Penelitian Sharma (2013:7) dan Pervan, Visic dan Barnjak (2015:1456) menyatakan bahwa profitability ratio mengalami penurunan yang signifikan. Sharma (2013:7) juga berpendapat bahwa liquidity ratio dan solvency ratio tidak mengalami peningkatan signifikan setelah merger dan akuisisi dilakukan. Penelitian Tarigan, Claresta dan Hatane (2018:108) memiliki hasil bahwa merger dan akuisisi berpengaruh signifikan terhadap current ratio, total asset turnover, debt to equity ratio dan kinerja pasar namun tidak berpengaruh signifikan terhadap net profit margin, return on assets, return on equity, earnings per share.

\section{HIPOTESIS PENELITIAN}

$\mathrm{Ha}$ : Tingkat kinerja perusahaan mengalami perubahan yang signifikan sesudah merger dan akuisisi dibandingkan sebelum merger dan akuisisi dilakukan.

$\mathrm{Hb} \quad$ : Tingkat kinerja pasar perusahaan mengalami perubahaan yang signifikan sesudah merger dan akuisisi dibandingkan sebelum merger dan akuisisi dilakukan.

\section{METODOLOGI PENELITIAN}

Metode yang digunakan dalam penelitian ini adalah metode komparatif yaitu penelitian yang bersifat membandingkan kinerja keuangan dan pasar perusahaan sebelum dan sesudah melakukan merger dan akuisisi. Penelitian ini menggunakan data cross-section dengan periode penelitian yang dimulai dari tahun 2009-2017 untuk perusahaan yang melakukan merger dan akuisisi pada tahun 2012-2014. Sumber data penelitian menggunakan laporan keuangan perusahaan terbuka non-keuangan yang terdaftar di Bursa Efek Indonesia dan melakukan merger dan akuisisi pada periode yang telah ditentukan yang datanya diperoleh dari website Komisi Pengawas Persaingan Usaha (KPPU). Teknik pemilihan sampel yang digunakan adalah purposive sampling dengan kriteria perusahaan non-keuangan yang terdaftar di Bursa Efek Indonesia dan melakukan merger dan akuisisi serta mengumumkan aktivitas tersebut pada 
periode tahun 2012 sampai 2014 dan masih beroperasi sampai saat penelitian ini dilakukan, memiliki laporan keuangan publikasian di Bursa Efek Indonesia untuk periode 3 tahun sebelum dan 3 tahun sesudah merger dan akuisisi dan tidak melakukan aktivitas merger dan akuisisi kembali dalam jangka waktu 3 tahun sebelum dan 3 tahun sesudah tanggal merger dan akuisisi yang ditentukan. Berdasarkan kriteria tersebut maka jumlah sampel dalam penelitian ini terdiri dari 16 perusahaan. Operasionalisasi variabel pada penelitian ini adalah membandingkan kinerja keuangan dan kinerja pasar sebelum dan sesudah merger dan akuisisi yang ditunjukkan pada table 1 berikut:

Tabel 1. Operasionalisasi Variabel

\begin{tabular}{|l|l|l|}
\hline \multicolumn{1}{|c|}{ Tipe } & \multicolumn{1}{|c|}{ Rasio } & \multicolumn{1}{c|}{ Definisi } \\
\hline \multirow{4}{*}{ Liquidity Ratio } & Current ratio & Current Assets / Current Liabilities \\
\cline { 2 - 3 } & Quick ratio & (Current Assets - Inventory) / Current Liabilities \\
\hline \multirow{5}{*}{ Profitability Ratio } & Total assets turnover & Sales / Total Assets \\
\cline { 2 - 3 } & Return on assets & Net Income / Total Assets \\
\cline { 2 - 3 } & Return on equity & Net Income / Shareholders Equity \\
\cline { 2 - 3 } Solvency Ratio & Earning per shares & $\begin{array}{l}\text { Earnings available for common stock / number of } \\
\text { shares of common stock outstanding }\end{array}$ \\
\cline { 2 - 3 } & Net profit margin & Net Income / Sales \\
\cline { 2 - 3 } & $\begin{array}{l}\text { Debt to equity ratio } \\
\text { earned }\end{array}$ & Total Debt / Total Assets \\
\hline \multirow{2}{*}{ Kinerja Pasar } & Tobin's Q Ratio & $\begin{array}{l}\text { (Market value of equity + Total Debt)/ Total } \\
\text { Assets }\end{array}$ \\
\hline
\end{tabular}

Terdapat dua jenis uji statistik yang akan digunakan dalam penelitian ini yaitu uji statistik deskriptif dan uji normalitas. Kedua pengujian tersebut dilakukan sebelum melakukan pengujian hipotesis. Uji statistik deskriptif digunakan untuk memberikan deskripsi mengenai data yang dilihat menggunakan nilai rata-rata (mean), standar deviasi, nilai maksimum, dan nilai minimum. Uji normalitas digunakan untuk menentukan distribusi data dalam penelitian yang berkaitan dengan metode yang akan digunakan untuk pengujian hipotesis. Dalam penelitian ini uji normalitas akan menggunakan uji statistik non-parametrik KolmogorovSmirnov, dimana apabila data berdistribusi secara normal maka pengujian hipotesis akan menggunakan uji parametrik paired sample t-test dan untuk data yang berdistribusi tidak normal akan menggunakan uji non-parametrik wilcoxon sign test.

\section{ANALISIS DAN PEMBAHASAN}

Uji Normalitas

Berikut ringkasan dari hasil uji normalitas menggunakan uji statistik non-parametrik Kolmogorov-Smirnov dengan tingkat signifikan $95 \%$.

Tabel 2. Hasil Uji Normalitas Kolmogorov-Smirnov

\begin{tabular}{|c|c|c|c|c|}
\hline Variabel & $\begin{array}{c}\text { Sig. Pre- } \\
\text { M\&A }\end{array}$ & $\begin{array}{c}\text { Sig. Post- } \\
\text { M\&A }\end{array}$ & Kesimpulan & Pengujian Hipotesis \\
\hline CR & 0,2000 & 0,0290 & Tidak Normal & Wilcoxon Signed test \\
\hline QR & 0,0480 & 0,0030 & Tidak Normal & Wilcoxon Signed test \\
\hline TATO & 0,0980 & 0,0100 & Tidak Normal & Wilcoxon Signed test \\
\hline ROA & 0,2000 & 0,2000 & Normal & Paired t-test \\
\hline ROE & 0,0030 & 0,0190 & Tidak Normal & Wilcoxon Signed test \\
\hline EPS & 0,0040 & 0,0000 & Tidak Normal & Wilcoxon Signed test \\
\hline
\end{tabular}




\begin{tabular}{|c|c|c|c|c|}
\hline \hline NPM & 0,0290 & 0,0000 & Tidak Normal & Wilcoxon Signed test \\
\hline DER & 0,0010 & 0,1620 & Tidak Normal & Wilcoxon Signed test \\
\hline TIER & 0,0000 & 0,0000 & Tidak Normal & Wilcoxon Signed test \\
\hline Q & 0,0800 & 0,0000 & Tidak Normal & Wilcoxon Signed test \\
\hline
\end{tabular}

Berdasarkan tabel 2 diatas, dapat disimpulkan bahwa seluruh variabel dalam penelitian akan diuji menggunakan Wilcoxon signed test kecuali variabel return on asset akan diuji menggunakan paired $t$-test karena datanya berdistribusi secara normal.

\section{Uji Hipotesis}

Berikut ringkasan dari hasil uji hipotesis menggunakan Wilcoxon signed test dan paired t-test.

Tabel 3. Hasil pengujian hipotesis

\begin{tabular}{|l|r|r|r|r|l|}
\hline Variabel & \multicolumn{1}{|c|}{$\begin{array}{c}\text { Mean } \\
(\mathbf{t}-3)\end{array}$} & $\begin{array}{c}\text { Mean } \\
(\mathbf{t}+\mathbf{3})\end{array}$ & \multicolumn{1}{c|}{ Selisih } & \multicolumn{1}{c|}{$\begin{array}{c}\text { Nilai } \\
\text { Signifikansi }\end{array}$} & \multicolumn{1}{|c|}{ Kesimpulan } \\
\hline CR & 1,553 & 1,643 & 0,090 & 0,918 & Ha1 ditolak \\
\hline QR & 1,053 & 1,197 & 0,143 & 1,000 & Ha2 ditolak \\
\hline TATO & 0,804 & 0,629 & $-0,174$ & 0,001 & Ha3 diterima \\
\hline ROA & 0,101 & 0,049 & $-0,090$ & 0,003 & Ha4 diterima \\
\hline ROE & 0,138 & 0,048 & $-0,090$ & 0,010 & Ha5 diterima \\
\hline EPS & 178,630 & 57,134 & $-121,495$ & 0,003 & Ha6 diterima \\
\hline NPM & 0,150 & $-1,476$ & $-1,627$ & 0,000 & Ha7 diterima \\
\hline DER & 0,690 & 1,028 & $-0,690$ & 0,408 & Ha8 ditolak \\
\hline TIER & 181,516 & 15,734 & $-165,781$ & 0,004 & Ha3 diterima \\
\hline Q & 1,485 & 1,281 & $-0,203$ & 0,070 & Hb1 ditolak \\
\hline
\end{tabular}

Berdasarkan tabel 3, rasio likuiditas yang diproksikan dengan CR dan QR menunjukkan peningkatan yang tidak signifikan dalam waktu 3 tahun setelah merger dan akuisisi. Peningkatan tidak signifikan ini menunjukkan bahwa adanya sedikit peningkatan kemampuan perusahaan untuk melunasi hutang jangka panjangnya menggunakan aset yang dimilikinya walaupun kenaikan tersebut tidak signifikan dan memiliki arti bahwa merger dan akuisisi belum dapat menunjukkan terjadinya sinergi. Rasio profitabilitas yang diproksikan dengan TATO, ROA, ROE, EPS dan NPM menunjukkan terjadi perubahaan signifikan bernilai negatif yang berarti terjadi penurunan kinerja profitabilitas sesudah merger dan akuisisi. Komponen penting dalam rasio profitabilitas ini adalah pendapatan. Dengan adanya perubahan bernilai negatif dapat disimpulkan bahwa merger dan akuisisi ini belum dapat meningkatkan pendapatan dari perusahaan yang melakukan kegiatan ini. Peningkatan pendapatan yang tidak terjadi merupakan akibat dari sinergi yang belum terbentuk dari merger dan akuisisi yang dilakukan oleh perusahaan. Rasio solvabilitas yang diproksikan dengan DER dan TIER menunjukkan tidak terjadi perubahan signifikan untuk periode 3 tahun sesudah merger dan akuisisi. Merger dan akuisisi dianggap kurang berhasil meningkatkan sinergi keuangan pada perusahaan yang melakukannya.

Kinerja pasar yang diukur menggunakan rasio Tobin's Q juga menunjukkan tidak terdapat perubahan yang signifikan untuk periode 3 tahun sesudah merger dan akuisisi. Penurunan tidak signifikan ini menunjukkan bahwa pasar modal di Indonesia tidak berekspektasi bahwa dengan dilakukannya merger dan akuisisi ini akan memberikan nilai tambah bagi perusahaan pengakuisisi dalam bentuk sinergi. 


\section{KESIMPULAN}

Tujuan umum yang ingin dicapai dari kegiatan merger dan akuisisi adalah memperoleh suatu sinergi yang dapat menguntungkan masing-masing pihak dalam merger dan akuisisi. Sinergi dalam penelitian Eliasson (2011:1) mengacu pada efek yang timbul antara dua atau lebih entitas yang menghasilkan efek lebih besar daripada jumlah efek secara individual. Untuk dapat memperoleh hasil yang maksimal dari merger dan akuisisi ini memerlukan investasi waktu yang lebih panjang untuk terus melakukan integrasi operasional perusahaan.

Berdasarkan hasil penelitian hipotesis yang sudah dilakukan dapat disimpulkan bahwa tidak semua rasio keuangan dan rasio pasar mengalami perubahan yang signifikan sesudah perusahaan melakukan merger dan akuisisi. Peningkatan dan penurunan dari masing-masing rasio dalam penelitian ini yang sifatnya masih tidak signifikan merupakan hasil dari efisiensi operasi yang belum tercapai sepenuhnya pada perusahaan yang melakukan merger dan akuisisi.

\section{SARAN}

Untuk penelitian dimasa yang akan datang sebaiknya menggunakan periode yang lebih panjang untuk mengamati apakah suatu sinergi dapat tercipta dari kegiatan merger dan akuisisi ini. Penambahan acuan jurnal dan variabel yang diuji juga dapat dilakukan untuk lebih memrepresentasikan keadaan yang sesungguhnya.

\section{DAFTAR PUSTAKA}

Eliasson, Sofie. (2011). Synergies in Merger and Acquisitions. Master Thesis in Business Administration

Gaughan, P. A. (2007). Mergers, Acquisitions, and Corporate Restructurings. John Wiley \& Sons

Harjito, D. Agus dan Zunaidah Sulong. The effect of merger and acquisition announcements on stock price behavior and financial performance changes: a case of banks in Malaysia. Sinergi Kajian Bisnis dan Manajemen Vol. 8 No.1 Januari 2006. hal 1-12

Payamta dan Setiawan D. (2004). Analisis pengaruh Merger dan Akuisisi Terhadap Kinerja Perusahaan Publik di Indonesia. Jurnal Riset Akuntansi Indonesia Vol. 7 No. 3. hal 265282

Pervan, Maja, Josipa Visic dan Kristina Barnjak. (2016). The impact of M\&A on company performance: Evidence from Croatia. Procedia Economics and Finance 23. hal 14511456

Sharma, Sonia. (2013). Measuring Post-Merger Performance: A Study of Metal industry. International Journal of Applied Research and Studies. hal 1-8

Tarigan, Yosua, Swenjiadi Yenewan, dan Grace Natalia. (2016). Merger dan Akuisisi dari Perspektif Strategis dan Kondisi Indonesia (Pendekatan Konsep \& Studi Kasus). Yogyakarta: Ekuilibria

Tarigan, Yosua, Alfonsis Claresta, dan Saarce Elyse Hatane. (2018). Analysis Merger and Acquisition Motives in Indonesian Listed Companies Through Financial Performance Perspective. Kinerja Volume 22 No.1. hal 95-112

Weygandt, Jerry J, Paul D Kimmel, dan Donald E Kieso. (2015). Financial Accounting: IFRS $3^{\text {rd }}$ Edition. USA: John Willey \& Sons Inc

www.idx.co.id

www.kppu.go.id 